\title{
The Utilization of Soybean Meal in Formulated Diet for Marble Goby, Oxyeleotris marmoratus
}

\author{
Annita Seok Kian Yong ${ }^{1}$, Shing Yau Ooi ${ }^{1} \&$ Rossita Shapawi ${ }^{1}$ \\ ${ }^{1}$ Borneo Marine Research Institute, Universiti Malaysia Sabah, Malaysia \\ Correspondence: Annita Seok Kian Yong, Universiti Malaysia Sabah, Jalan UMS 88400, Kota Kinabalu, Sabah, \\ Malaysia. Tel: 60-8832-0000 ext. 2589. E-mail: annitay@ums.edu.my
}

Received: August 13, 2013

Accepted: September 22, 2013 Online Published: October 15, 2013

doi:10.5539/jas.v5n11p139

URL: http://dx.doi.org/10.5539/jas.v5n11p139

\begin{abstract}
Marble goby, Oxyeleotris marmoratus is a carnivorous fish that highly demanded in Asia region and has great potential in aquaculture industry. A feeding trial was conducted to investigate the possibility of replacing fishmeal with soybean meal in the diet for marble goby juvenile. Fish (initial body weight and length $0.28 \pm 0.01 \mathrm{~g}$ and $2.60 \pm 0.04 \mathrm{~cm}$ respectively) were fed with four isonitrogenous and isolipidic diets, which contained $0 \%, 10 \%$ and $20 \%$ of defatted soybean meal (SB0, SB10 and SB20, respectively) and $20 \%$ of soybean meal supplemented with $2000 \mathrm{FTU} / \mathrm{kg}$ phytase (SB20+P). The fish were randomly distributed into 12L aquariums and hand-fed till apparent satiation twice daily. After 40-day of feeding trial, highest growth was observed in fish fed SB0, without significant difference with fish fed SB10; both groups were significant better than juveniles fed SB20 and SB20+P. Treatment SB20+P obtained slightly higher growth than those fed SB20. Similar trend was observed in the specific growth rate, feed conversion ratio and nitrogen retention efficiency. Protein efficiency ratio of fish fed SB0, SB10 and SB20+P was significant higher than fish fed SB20. The body lipid content was significantly reduced in higher soybean meal level diet partly due to starvation as the fish were reluctant to feed on experimental diet. No distinct enteritis symptoms was observed in juveniles fed SB0 and SB10 while juveniles fed SB20+P had better intestinal morphology than in SB20. In conclusion, young marble goby juvenile can utilize $10 \%$ of defatted soybean meal in their diet without affecting its growth, nutrient utilization and intestinal condition.
\end{abstract}

Keywords: marble goby juvenile, Oxyeleotris marmoratus, soybean meal, growth performance, nutrient utilization

\section{Introduction}

Marble goby, scientifically known as Oxyeleotris marmoratus, is a carnivorous fish that occurs in freshwater as well as brackish water system in Southeast Asia, Taiwan and China (Allen, 2011). The maximum body length and body weight of marble goby recorded were approximately $65 \mathrm{~cm}$ and $2 \mathrm{~kg}$ (Kechik, 1995; Kottelat, 2001). It is a delicacy lean fish with excellent meat texture and has a lucrative market in the Asian region (Sreevatana, 1993; Masagca \& Sumantadinata, 1994; Sverdrup-Jensen, 2002). In Malaysia, since the early 1980's this fish had attracted the attention of aquaculturist to produce seedling for aquaculture production (Tan \& Lam, 1973; Tavarutmaneegul \& Lin, 1988; Cheah et al., 1994; Senoo et al., 1994). Although mass production of marble goby is yet established; the attractive market price and high demand make it a great potential species for aquaculture production.

Recent years, the global fishmeal demand has far exceeded its supply. As fishmeal provides the major protein component in formulated feed, various efforts had been undertaken to find alternative protein sources to replace fishmeal in feed production (Francis et al., 2001; Shapawi et al., 2007; Hardy, 2010; Cheng et al., 2010; Yu et al., 2012). Plant-based protein such as defatted soybean meal is widely utilized in the production of feed for either terrestrial or aquatic animals (Dei, 2011). This plant protein has becomes one of the most promising alternative sources to replace fishmeal due to its lower price and sustainable supplies (Kikuchi \& Furuta, 2009), high protein content with a relatively balanced of amino acid profile and reported to be palatable to most of the fish species (Lim \& Akiyama, 1992).

The utilization of soybean meal in the diet for aquaculture species is well documented (Pantha, 1982; Webster et al., 1992; Kikuchi \& Furuta, 2009; Lim et al., 2011; Antolović et al., 2012; Shapawi et al., 2013a). However, the use of soybean meal is limited in monogastric animal such as fish due to the presence of anti-nutritional factors 
(Bureau et al., 1998; Peres et al., 2003). Most of the carnivorous fish were recorded to be able to accept $10-40 \%$ of soybean meal (Tantikitti et al., 2005; Kikuchi \& Furuta, 2009; Yigit et al., 2010; Lim et al., 2011; Yu et al., 2012; Antolović et al., 2012). However, some carnivorous and omnivorous fish such as European seabass, blue catfish and tilapia can accept up to $75-100 \%$ replacement by using soybean meal (Pantha, 1982; Webster et al., 1992; Kaushik et al., 2004). The ability to utilize soybean meal-based diet is species-specific (Forster, 2002; Gatlin, 2002) and the use of soybean meal by marble goby juvenile has yet been investigated. In this study, feeding trial was conducted to investigate the level of soybean meal that can be utilized by younger marble goby juvenile based on their growth performance, nutrient utilization and intestinal condition after feeding with soybean meal-based and phytase supplemented soybean meal-based diets.

\section{Methods}

\subsection{Experimental Diets}

Four diets were formulated to replace $0 \%, 10 \%$ and $20 \%$ of fishmeal protein by soybean meal and another diet with $20 \%$ of soybean meal supplemented with 2000 FTU/kg diet phytase as SB0, SB10, SB20 and SB20+P, respectively (Table 1). Danish fishmeal and defatted soybean meal from China were used as the main protein sources. All diets were formulated to contain $45 \%$ of dietary protein and $10 \%$ of dietary lipid. The experiment diets were prepared by weighing all the dry ingredients separately. Then these ingredients were mixed thoroughly and subsequently fish oil was added. Phytase was dissolved in water before adding into the mixture. This mixture was screw-pressed through a 3-mm die with a meat mincer then was oven-dried at $40^{\circ} \mathrm{C}$ and $\mathrm{kept}$ refrigerated at $-20^{\circ} \mathrm{C}$ until used. All diets were subjected to proximate analysis before the commencing of the feeding trial. Protein content of the diets was in the range of 46.0-47.5\% (Table 2) while lipid content of diets was in range of $9.8-10.5 \%$. The gross energy content of diets ranged from $16.2-17.6 \mathrm{~kJ} / \mathrm{g}$ of diet was estimated by multiplying the average caloric conversion factors which are $23.4 \mathrm{~kJ} / \mathrm{g}, 39.8 \mathrm{~kJ} / \mathrm{g}$ and $17.6 \mathrm{~kJ} / \mathrm{g}$ for protein, lipid, and carbohydrate content, respectively (Henken et al., 1986).

Table 1. Formulation of experimental diets contained different level of soybean meal and phytase supplementation (dry weight basis)

\begin{tabular}{lcccc}
\hline \multirow{2}{*}{ Ingredients (g/100 g) } & \multicolumn{4}{c}{ Dietary treatments } \\
\cline { 2 - 5 } & SB0 & SB10 & SB20 & SB20+P \\
\hline Fishmeal $^{\mathrm{a}}$ & 53.3 & 47.5 & 41.8 & 41.8 \\
Soybean meal $^{\mathrm{b}}$ & 0 & 8.9 & 17.8 & 17.8 \\
Wheat gluten $_{\text {Starch }}$ & 4.0 & 4.0 & 4.0 & 4.0 \\
Fish oil $_{\text {Vitamin }}^{\mathrm{c}}$ & 0.9 & 0.9 & 0.9 & 0.9 \\
Mineral $^{\mathrm{c}}$ & 5.8 & 6.2 & 6.6 & 6.6 \\
Alfa cellulose $_{\text {Carboxymethylcellulose }}$ & 3.0 & 3.0 & 3.0 & 3.0 \\
Phytase $^{\mathrm{d}}$ & 2.0 & 2.0 & 2.0 & 2.0 \\
& 29.0 & 25.5 & 21.9 & 21.9 \\
& 2.0 & 2.0 & 2.0 & 2.0 \\
& 0 & 0 & 0 & 0.02 \\
\hline
\end{tabular}

${ }^{a}$ Danish fish meal.

${ }^{\mathrm{b}}$ Defatted soybean meal.

${ }^{\mathrm{c}}$ Halver's mixture (1957).

${ }^{\mathrm{d}}$ Natuphos $^{\circledR}$ 10,000G (10,000 FTU/g) BASF Mumbai, India. (1 unit of phytase (FTU) can liberates 1 micromol of inorganic phosphorus per minute from $0.0051 \mathrm{MOL} / \mathrm{L}$ of sodium phytate at $\mathrm{pH} 5.5$ and $37^{\circ} \mathrm{C}$ ). 
Table 2. Proximate composition of experimental diets

\begin{tabular}{|c|c|c|c|c|}
\hline \multirow[b]{2}{*}{ Proximate analysis (\%) } & \multicolumn{4}{|c|}{ Dietary treatments } \\
\hline & SB0 & SB10 & SB20 & SB20+P \\
\hline Crude protein & $47.5 \pm 0.1$ & $46.0 \pm 0.2$ & $46.4 \pm 0.4$ & $47.1 \pm 0.2$ \\
\hline Crude lipid & $9.9 \pm 0.3$ & $10.2 \pm 0.2$ & $10.5 \pm 0.1$ & $9.8 \pm 0.0$ \\
\hline Crude fiber & $26.7 \pm 0.5$ & $24.8 \pm 0.9$ & $19.2 \pm 0.1$ & $19.5 \pm 0.6$ \\
\hline Dry matter & $94.4 \pm 0.1$ & $94.1 \pm 0.2$ & $93.9 \pm 0.4$ & $94.4 \pm 0.3$ \\
\hline Ash & $9.4 \pm 0.1$ & $9.5 \pm 0.1$ & $9.3 \pm 0.2$ & $8.9 \pm 0.1$ \\
\hline Nitrogen-free extract (NFE) ${ }^{a}$ & $6.5 \pm 0.8$ & $9.5 \pm 1.2$ & $14.6 \pm 0.6$ & $14.4 \pm 0.8$ \\
\hline Gross energy $(\mathrm{kJ} / \mathrm{g})^{\mathrm{b}}$ & $16.2 \pm 0.1$ & $16.5 \pm 0.1$ & $17.6 \pm 0.0$ & $17.5 \pm 0.1$ \\
\hline
\end{tabular}

\subsection{Fish and Experiment Design}

This feeding trial was conducted in Borneo Marine Research Institute of Universiti Malaysia Sabah (UMS), Malaysia. Fish specimens approximately $1 \mathrm{~cm}$ body length (BL) used in this feeding trial were obtained from the fish hatchery of UMS. These fish were acclimatized to experimental condition and weaned to formulated diet prior to feeding trial.

Groups of 20 fish of initial body weight (BW) and BL of $0.28 \pm 0.01 \mathrm{~g}$ and $2.60 \pm 0.04 \mathrm{~cm}$, respectively were randomly distributed into 12 litre $(\mathrm{L})$ aquariums $(17 \mathrm{~cm}$ x $23 \mathrm{~cm}$ x $31 \mathrm{~cm})$. A simple recirculation water system using dechlorinated tap water and coral rubble as filter was used in this feeding trial and about $20-30 \%$ of water was exchanged daily during bottom cleaning. Water quality was maintained at temperature $28.25 \pm 0.82{ }^{\circ} \mathrm{C}$, dissolved oxygen (DO) at $6.98 \pm 0.22 \mathrm{mg} / \mathrm{L}$ and $\mathrm{pH}$ at $7.25 \pm 0.30$.

Triplicate groups of fish in each treatment were hand fed till apparent satiation twice daily in 09:00 and 14:00 h. Uneaten feed was siphoned out 2 hours after feeding to estimate the feed conversion ratio. Body weight measurements of the fish were done every 2 weeks intervals and the fish were anesthetized (Transmore 50ppm, Nika Trading Co.) before measurement. At the end of the feeding trial, fish $(n=10)$ from each treatment were sampled and kept in $-20^{\circ} \mathrm{C}$ for analysis.

\subsection{Proximate Analysis}

Fish carcasses from each treatment were minced thoroughly before analysis. Moisture content of the fish and feed was determined by oven-dried at $105^{\circ} \mathrm{C}$ overnight till constant weight was obtained; ash content was determined after sample was incinerated in muffle furnace at $550^{\circ} \mathrm{C}$ for 5 hours. Crude protein $(\mathrm{N} \times 6.25)$ was determined by an automatic Kjeldahl ${ }^{\mathrm{TM}} 2300$ protein analyzer (FOSS Tecator, Sweden). Crude lipid was determined by petroleum benzene-extraction method using Soxtec ${ }^{\mathrm{TM}} 2043$ Hot Extraction (FOSS Tecator, Sweden). Crude fiber was determined by weak sulphuric acid and sodium hydroxide digestion using Fibertec System 1021 Cold Extractor and Hot Extractor (FOSS Tecator, Sweden), and dried in oven at $130^{\circ} \mathrm{C}$ for 2 hours and finally incinerated in furnace at $525^{\circ} \mathrm{C}$ for 3 hours.

\subsection{Histological Examination}

Intestine of some fish was sampled from each treatment $(n=6)$ to examine the condition of the intestine after feeding with soybean meal based diets. The intestine was preserved in Bouin's solution (saturated picric acid solution, formaldehyde $37 \%$ and glacial acetic acid at a ratio of 15:5:1) (Bancroft, 2008) followed by dehydration process in a series of increasing alcohol concentration, embedded in paraffin, finally cut into $6 \mu \mathrm{m}$ thickness by using microtome. The cut sections were gently placed on the slide glass and stained with haematoxylin and eosin (Culling, 1974) before observed under a light microscope (Nikon Eclipse 80i).

\subsection{Statistical Analysis}

Data was analyzed by using one-way Analysis of Variance to test the differences of all observed parameter in this feeding trial. Tukey's test was further conducted when mean value was found to be significant at $P<0.05$. Data in percentage was arcsine transformed prior to data analysis. All data were presented as mean \pm standard 
deviation (SD). This analysis was performed by using the Statistical Package for Social Sciences (SPSS) program 16.00 for Windows.

\section{Results}

\subsection{Growth Performance and Nutrient Utilization}

Both the BW and BL of initial fish were not significant among each treatment $(P>0.05)$ (Table 3). After 40-day of feeding trial, the highest growth was achieved by marble goby juvenile fed control diet (SB0) (129.0\%) without significant different with juveniles fed SB10 (101.2\%) $(P>0.05)$. However, both treatments showed significant higher growth compared to juvenile fed SB20 and SB20+P $(P<0.05)$. Besides, juvenile fed SB20+P obtained slightly higher growth (28.5\%) than juvenile fed SB20 diet without supplementation of phytase (20.8\%). Similar trend was also shown in the final BW and specific growth rate (SGR). Low survival (50-68.3\%) was observed in fish fed diets contained soybean meal (SB10, SB20 and SB20+P) compared to SB0.

Table 3. Growth performances and nutrient utilization of marble goby fed experimental diets

\begin{tabular}{|c|c|c|c|c|}
\hline \multirow[b]{2}{*}{ Parameters $^{1}$} & \multicolumn{4}{|c|}{ Dietary treatments } \\
\hline & SB0 & SB10 & SB20 & SB20+P \\
\hline Initial body weight $(\mathrm{BW})(\mathrm{g})$ & $0.28 \pm 0.01$ & $0.28 \pm 0.01$ & $0.28 \pm 0.01$ & $0.28 \pm 0.01$ \\
\hline Final BW(g) & $0.64 \pm 0.07^{\mathrm{b}}$ & $0.56 \pm 0.08^{\mathrm{b}}$ & $0.34 \pm 0.01^{\mathrm{a}}$ & $0.36 \pm 0.02^{\mathrm{a}}$ \\
\hline Initial body length $(\mathrm{BL})(\mathrm{cm})$ & $2.6 \pm 0.7$ & $2.6 \pm 0.1$ & $2.6 \pm 0.1$ & $2.6 \pm 0.1$ \\
\hline Final BL $(\mathrm{cm})$ & $3.3 \pm 0.1$ & $3.2 \pm 0.1$ & $2.9 \pm 0.3$ & $2.8 \pm 0.1$ \\
\hline Growth (\%) & $129.0 \pm 27.3^{\mathrm{b}}$ & $101.2 \pm 33.2^{\mathrm{b}}$ & $20.8 \pm 2.0^{\mathrm{a}}$ & $28.5 \pm 8.7^{\mathrm{a}}$ \\
\hline Specific growth rate (SGR)(\%growth/day) ${ }^{2}$ & $2.1 \pm 0.3^{\mathrm{b}}$ & $1.7 \pm 0.4^{\mathrm{b}}$ & $0.5 \pm 0.0^{\mathrm{a}}$ & $0.6 \pm 0.2^{\mathrm{a}}$ \\
\hline Survival (\%) & $88.3 \pm 11.6^{\mathrm{b}}$ & $58.3 \pm 11.6^{\mathrm{ab}}$ & $50.0 \pm 13.2^{\mathrm{a}}$ & $68.3 \pm 7.6^{\mathrm{ab}}$ \\
\hline
\end{tabular}

${ }^{1}$ Values are mean $\pm \mathrm{SD}$ of $(\mathrm{n}=3)$.

${ }^{2}$ SGR $(\%$ growth/day $)=100 \times[\operatorname{In}($ Final BW(g) $)-\operatorname{In}(\operatorname{Initial~BW}(\mathrm{g}))] /$ days of feeding trial.

Feed conversion ratio (FCR) of fish fed SB10 (2.0) was comparable to fish fed SB0 (1.8) $(P>0.05)$ (Table 4). FCR of juvenile fed SB20+P (2.9) was significant poorer than SB0; however it was significant better than juvenile fed SB20 (4.0) $(P<0.05)$. The protein efficiency ratio (PER) of juveniles fed SB0, SB10 and SB20+P was not significant different among each other $(1.1,0.9$ and 0.9 , respectively); however, these treatments were significant higher than juvenile fed SB20 $(0.3)(P<0.05)$. The nitrogen retention efficiency (NRE) of juvenile fed SB10 $(9.1 \%)$ was not significant $(P>0.05)$ with the juvenile fed SB0 (18.2\%). Other treatments (SB20 and $\mathrm{SB} 20+\mathrm{P})$ showed negative values of NRE and were significantly lower than SB0 and SB10 $(P<0.05)$.

Table 4. Nutrient utilization of marble goby juvenile fed experimental diets

\begin{tabular}{lcccc}
\hline \multirow{2}{*}{ Parameters $^{1}$} & \multicolumn{3}{c}{ Dietary treatments } \\
\cline { 2 - 5 } & SB0 & SB10 & SB20 & SB20+P \\
\hline Feed conversion ratio (FCR) $^{2}$ & $1.8 \pm 0.1^{\mathrm{a}}$ & $2.0 \pm 0.2^{\mathrm{ab}}$ & $4.0 \pm 0.5^{\mathrm{c}}$ & $2.9 \pm 0.2^{\mathrm{b}}$ \\
Protein efficiency ratio (PER) $^{3}$ & $1.1 \pm 0.1^{\mathrm{b}}$ & $0.9 \pm 0.1^{\mathrm{b}}$ & $0.3 \pm 0.1^{\mathrm{a}}$ & $0.9 \pm 0.3^{\mathrm{b}}$ \\
Nitrogen retention efficiency (NRE \%) $^{4}$ & $18.2 \pm 3.3^{\mathrm{b}}$ & $9.1 \pm 1.3^{\mathrm{b}}$ & $-4.4 \pm 4.1^{\mathrm{a}}$ & $-2.2 \pm 7.4^{\mathrm{a}}$ \\
\hline
\end{tabular}

${ }^{1}$ Values are mean $\pm \mathrm{SD}$ of $(\mathrm{n}=3)$.

${ }^{2} \mathrm{FCR}=$ Total feed consumed $(\mathrm{g}) /$ Weight gained of fish $(\mathrm{g})$.

${ }^{3} \mathrm{PER}=$ Weight gained $(\mathrm{g}) /$ protein intake $(\mathrm{g})$.

${ }^{4} \mathrm{NRE}=100 \mathrm{x}$ [Nitrogen gained $(\mathrm{g} /$ fish $) /$ nitrogen intake $\left.(\mathrm{g} / \mathrm{fish})\right]$. 


\subsection{Whole Body Proximate Analysis}

Whole body proximate composition of marble goby juvenile is shown in Table 5. The whole body protein content of marble goby juvenile (14.6-16.9\%) showed no significant different $(P>0.05)$ among all the treatments. However, body lipid content of juvenile fed SB0 and SB10 were significant higher $(P<0.05)$ than fish fed SB20 and SB20+P. Body moisture content of fish fed SB10 was the highest $(62.4 \%)$ while the lowest in fish fed SB20+P, without significantly influenced by the dietary treatments $(P>0.05)$. Body ash content of fish increased with the increasing level of soybean meal; fish fed SB0 showed significant lower body ash $(P<0.05)$ compared to fish fed SB20 and SB20+P (21.6\% and 22.4\%, respectively); however, no significant difference with fish fed $\operatorname{SB} 10(18.4 \%)(P>0.05)$.

Table 5. Whole body proximate analysis of marble goby juvenile fed experimental diets

\begin{tabular}{lcccc}
\hline & \multicolumn{4}{c}{ Dietary treatments } \\
\cline { 2 - 5 } Proximate Analysis (\%) & SB0 & SB10 & SB20 & SB20+P \\
\hline Protein & $16.9 \pm 0.9$ & $15.7 \pm 0.3$ & $15.4 \pm 1.4$ & $14.6 \pm 0.8$ \\
Lipid & $2.1 \pm 0.1^{\mathrm{c}}$ & $1.6 \pm 0.2^{\mathrm{c}}$ & $0.4 \pm 0.1^{\mathrm{a}}$ & $0.9 \pm 0.2^{\mathrm{b}}$ \\
Moisture & $60.4 \pm 1.7$ & $62.4 \pm 0.8$ & $60.1 \pm 1.4$ & $59.4 \pm 1.7$ \\
Ash & $18.0 \pm 1.8^{\mathrm{a}}$ & $18.4 \pm 0.5^{\mathrm{ab}}$ & $21.6 \pm 1.3^{\mathrm{bc}}$ & $22.4 \pm 0.5^{\mathrm{c}}$ \\
\hline
\end{tabular}

${ }^{1}$ Values are mean \pm SD of $(n=10)$.

\subsection{Intestinal Morphology}

Morphological changes of intestine in marble goby juveniles fed the experimental diets are shown in Figure 1. Juveniles fed SB0 did not showed any sign of enteritis (Figure 1A). The mucosal folds were in normal shape like a finger and the supranuclear vacuoles (SNV) were aligned lengthwise. Almost similar morphology appearance was observed in the intestine of juvenile fed SB10 (Figure 1B). Numerous large vacuoles (LV) were observed on the lamina epithelialis of juveniles fed SB20 (Figure 1C). Juveniles fed SB20+P had almost similar intestinal morphology (Figure 1D) with juveniles fed SB0 and the mucosal fold was in normal shape compared to the juveniles fed SB20 and less large vacuoles were observed.

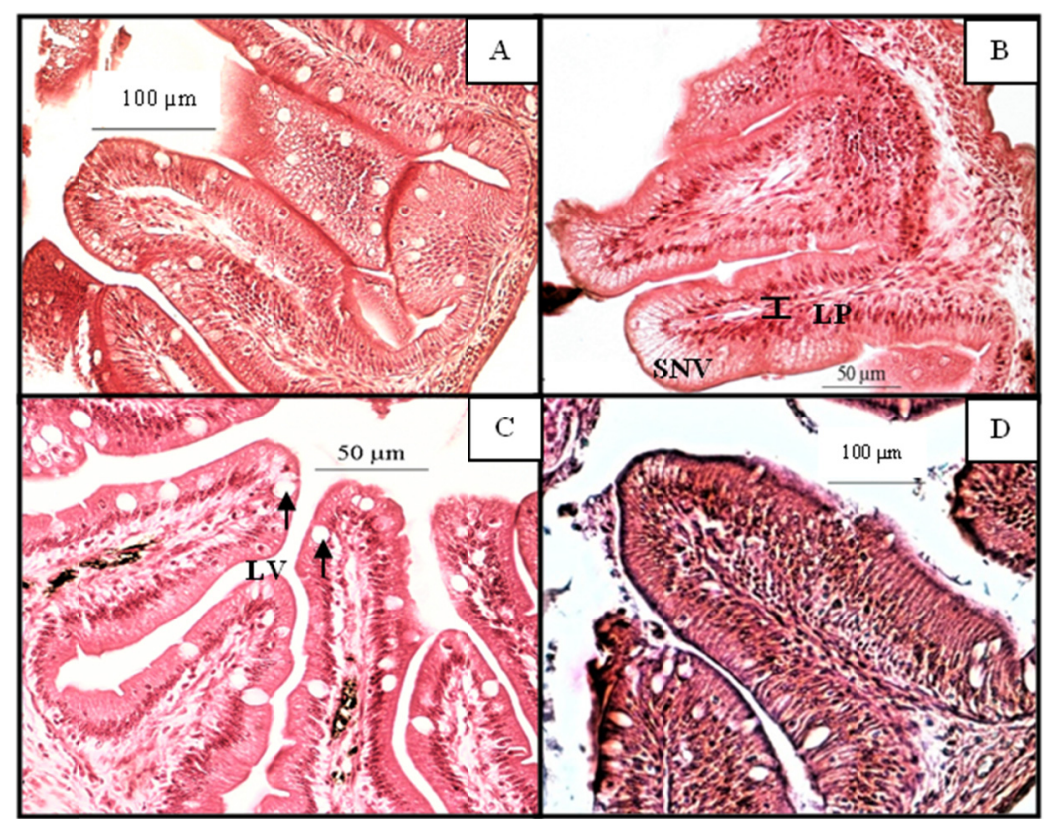

Figure 1. Intestinal morphology of marble goby juvenile. A) Appearance of intestinal morphology of juveniles fed with SB0, B) SB10, C) SB20 and D) SB20+P. LP=lamina propria; LV=large vacuole; SNV=supranuclear vacuoles 


\section{Discussion}

The amount of phytase applied in this study was $2000 \mathrm{FTU} / \mathrm{kg}$ diet with reference to the studies by Biswas et al. (2007) and Laining et al. (2011). In this present study, the growth performance, nutrient utilization efficiency and intestinal morphology of fish fed SB10 were not significant different with juveniles fed control diet (SB0). Fish fed SB0 and SB10 achieved more than $100 \%$ of growth in this 40-day trial. Further increased of soybean meal protein above $10 \%$ had reduced the growth and nutrient utilization efficiency significantly $(P<0.05)$ and showed intestinal enteritis symptoms as demonstrated in juveniles fed SB20 compared to juveniles fed SB0 and SB10. The supplementation of phytase in the SB20+P diet had improved the growth and nutrient utilization of the marble goby juvenile compared to juvenile fed SB20 although no significant difference was observed.

In general, size of fish is one of the factors that reported to influence the ability of the fish to accept soybean meal in replacement of fishmeal (Francis et al., 2001; Bonaldo et al., 2006). In this study, fish with an initial BW of $0.28 \mathrm{~g}$ were used. Based on the results, these fish can accept $10 \%$ of defatted soybean meal. The results are similar to that reported by Tantikitti et al. (2005) on Asian seabass juvenile (Lates calcarifer) where fish of initial BW $0.95 \mathrm{~g}$ can accept defatted soybean meal in replacement of fishmeal at a maximum level of $10 \%$. A 28-day old Pacific bluefin tuna (Thunnus orientalis) of initial BW $0.38 \mathrm{~g}$ can also utilized $10 \%$ of soybean meal (Biswas et al., 2011). The acceptance level of soybean meal by the marble goby juveniles in present study however, is lower compared to other bigger size of carnivorous fish reported elsewhere. Shapawi et al. (2013a) demonstrated that tiger grouper juvenile (Epinephelus fuscoguttatus) of initial BW $13.9 \mathrm{~g}$ can accept 20-30\% of defatted soybean meal protein without adversely affected their growth and feed utilization. Black sea turbot (Psetta maeotica) with an initial BW of $30.2 \mathrm{~g}$ can utilize up to $20 \%$ of defatted soybean meal with the supplementation of attractant (Yigit et al., 2010). Kikuchi and Furuta (2009) also demonstrated that tiger puffer (Takifugu rubripes) with an initial BW of $18 \mathrm{~g}$ can accept $30-40 \%$ of defatted soybean meal diet with the inclusion of $10-20 \%$ of blue mussel extract. However, a study by Antolović et al. (2012) showed that a smaller size of saddled bream juvenile (Oblada melanura) of initial BW $1.1 \mathrm{~g}$ was reported to be able to accept diet containing up to $28 \%$ of defatted soybean meal without any supplementation of essential amino acid. Besides the size of the fish, these varies results might be due to species - specific tolerance limit to the anti-nutritional factors, quality and methods processing of soybean meal, different supplementation of enzyme or amino acid (Elangovan \& Shim, 2000; Francis et al., 2001; Bonaldo et al., 2006).

It is well documented that feeding the fish with soybean meal diet higher than the tolerance limit can induce slower growth (Antolović et al., 2012; Yang et al., 2010; Lim et al., 2011; Yu et al., 2012; Shapawi et al., 2013a). In this present study, the growth of marble goby juveniles fed SB0 and SB10 was significant higher than fish fed SB20 and SB20+P. The FCR, PER and NRE of marble goby fed SB10 were as good as those observed in juvenile fed SB0 without significant difference $(P>0.05)$. However, the FCR and NRE was poorer when soybean meal protein was further increased to $20 \%$ and this have contributed to the slower growth of marble goby fed SB20 and SB20+P. Study on Chinese sucker (Myxocyprinus asiaticus) also showed a similar observation that the increase of soybean meal more than its optimum acceptance level at $40 \%$ had reduced the FCR and PER (Yu et al., 2012). Similar observations were demonstrated in other studies such as Asian seabass (Tankitti et al., 2005), rainbow trout (Yang et al., 2010) and tiger puffer (Lim et al., 2011).

The supplementation of phytase had shown to improve the growth performance and enhance the nutrient utilization significantly in SB20+P compared to SB20. Many studies had demonstrated the benefits of phytase supplementation in soybean meal-based diet to increase the bioavailability of protein and mineral for better feed efficiency and growth of fish (Biswas et al., 2007; Yang et al., 2010; Laining et al., 2011; Shapawi et al., 2013b). A study on red sea bream (Pagrus major) showed that the supplementation of $2000 \mathrm{FTU} / \mathrm{kg}$ phytase in the soybean meal-based diet showed a significant improvement in the weight gained of fish from $585.3 \%$ to $736.2 \%$, feed conversion efficiency from $75.1 \%$ to $82.3 \%$ compared to fish fed diet without supplementation of phytase (Biswas et al., 2007) and also fulfilled its dietary phosphorus requirement (Laining et al., 2011). Other similar studies were also reported in Nile tilapia fingerlings (Tahoun et al., 2009), rainbow trout juvenile (Oncorhynchus mykiss) (Yang et al., 2010; Castro et al., 2011), gibel carp (Carassius auratus gibelio) (Liu et al., 2011) and tiger grouper (Shapawi et al., 2013b). Besides, higher phytase supplementation of $4000 \mathrm{FTU} / \mathrm{kg}$ allowed the use of soybean meal up to $75 \%$ in the diet of rainbow trout juvenile with better growth performance and lower nitrogen excretion (Castro et al., 2011).

Studies reported that the deficient of methionine and lysine essential amino acid in the soybean meal can contribute to the loss of appetite, growth retardation and reduce feed consumption in several species of fish (Luo et al., 2006; Mai et al., 2006; Hansen et al., 2007; Zhou et al., 2007). During the feeding trial, it was observed that some of the juveniles expelled out the feed soon after they ingested the feed when given SB20 and SB20+P. 
This may indicate the unpalatability of the feed. The fishmeal and defatted soybean meal used in this present study were of the same sources with those used in tiger grouper study by Shapawi et al. (2013a) and the study reported that a deficiency of essential methionine amino acid was found in higher soybean meal-based diet compared to the control diet. Although amino acid analysis was not performed in this present study, with reference to Shapawi et al. (2013a), it is suggested that the diet contained high level of soybean meal SB20 and SB20+P contained less methionine amino acid compared to SB10. These could have contributed to the slower growth in marble goby juveniles fed higher level of soybean meal.

The varied level of soybean meal tested in this study did not significantly influence the body protein content of marble goby juvenile. However, the body lipid content of fish was significant lower when fed diet contained more than $10 \%$ of soybean meal protein as significant depletion of body lipid was observed in marble goby juvenile fed SB20 and SB20+P. Body lipid reduction in fish fed diets contained high level of soybean meal was also reported in tin foil barb juvenile, Barbodes altus (Elangovan \& Shim, 2000) and Atlantic salmon, Salmo salar (Weeks et al., 2010). The body lipid reduction in this present study may also due to starvation as the fish were reluctant to feed SB20 and SB20+P diets. The use of reserved body protein, lipid or glycogen by fish as primary metabolic fuel during starvation is species-specific (Mehner \& Wieser, 1994; Salam et al., 2000). The significant decreased of body lipid in the present study suggested that marble goby juveniles may utilize more of their lipid reserve as the main metabolic fuel during starvation. Lipid mobilization was also the first effect that can be observed in other fish species such as European bass, Dicentrachus labrax (Stirling, 1976), white sturgeon, Acipenser transmontanus (Hung et al., 1997) and Thaila (Catla catla) (Salam et al., 2000) during their starvation period. The body ash was significantly higher $(P<0.05)$ in fish fed higher soybean meal diet. A remarkably lower growth and nutrient utilization was also observed in fish fed higher soybean meal diet. Furthermore, fish fed SB20 and SB20+P showed negative value of NRE indicating that the fish may withdraw or use their body protein during the feeding trial, thus contributing to higher body ash content. This is similar with studies reported by Salam et al. (2000) and Ali et al. (2001).

Based on the histology observation, the appearance of the intestine of fish fed SB20 in this current study was almost similar with the soybean meal-induced enteritis symptoms as reported in Atlantic salmon (Urán et al., 2008). The typical signs of the intestinal mucosa are described as: a shortening of mucosal fold, a reduction of supranuclear vacuolization, increasing the abundance of large vacuole cells and so on (Urán, 2008; Krogdahl et al., 2000; Refstie et al., 2000). The defatted soybean meal used in present study is a commercial product that was subjected to heat and chemical extraction. These processes were reported to be able to eliminate some anti-nutritional factors especially the heat labile factors (Fagbenro, 1999). However, other anti-nutritional factors such as saponins and antigenic compound could be existed (Yang et al., 2010). Saponins in soybean product was reported to affect the fish appetite (Bureau et al., 1998) and it was also reported by Knudsen et al. (2007) that soya saponins, in combination with one or several unidentified components in soybean might induce inflammatory reaction in the distal intestine of Atlantic salmon. The presence of such anti-nutritional factors in the higher soybean meal level diets in this present study may lead to the poor appetite of the fish and the enteritis symptoms as observed in marble goby juvenile. Moreover, the fish used in this feeding trial is relatively smaller $(0.28 \mathrm{~g})$ and may be more sensitive to the anti-nutritional factors that present in the soybean meal-based diet. This is in agreement with studies on Senegalese sole, Solea senegalensis (Aragão et al., 2003) and gilthead sea bream, Sparus aurata (Venou et al., 2006).

In conclusion, this study showed that defatted soybean meal can be used to replace $10 \%$ of the fishmeal protein without adversely affecting the growth of young marble goby juveniles. The supplementation of phytase in the soybean meal-based diet has improved the growth and nutrient utilization, and reduced the intestinal enteritis symptoms of the marble goby. However, future study may be required to investigate the utilization of soybean meal by bigger size of marble goby juvenile.

\section{References}

Ali, M., Salam, A., \& Ali, Z. (2001). Dynamics of Body Composition, in Relation to Various Starvation Regimes of Chinese Grass Carp, Ctenopharyngodon idella (Val.). Pakistan Journal of Zoology, 33(10), 47-51.

Allen, D. (2011). Oxyeleotris marmorata. In: IUCN 2013. IUCN Red List of Threatened Species. Version 2013. Retrieved from www.iucnredlist.org

Antolović, N., Kožul, K., Antolović, M., \& Bolotin, J. (2012). Effects of partial replacement of fish meal by soybean meal on growth of juvenile saddled bream (Sparidae). Turkish Journal of Fisheries and Aquatic Sciences, 12(1-2), 1-6. http://dx.doi.org/10.4194/1303-2712-v12_2_08 
Aragão, C., Conceição, L. E. C., Dias, J., Marques, A. C., Gomes, E., \& Dinis, M. T. (2003). Soy protein concentrate as a protein source for Senegalese sole (Solea senegalensis Kaup 1858) diets: effects on growth and amino acid metabolism of postlarvae. Aquaculture Research, 34, 1443-1452. http://dx.doi.org/10.1111/j.1365-2109.2003.00971.x

Bancroft, J. D. (2008). Theory and practice of histological techniques (p. 70). Elsevier Health Sciences.

Biswas, A. K., Kaku, H., Ji, S. C., Seoka, M., \& Takii, K. (2007). Use of soybean meal and phytase for partial replacement of fish meal in the diet of red sea bream, Pagrus major. Aquaculture, 267, 284-291. http://dx.doi.org/10.1016/j.aquaculture.2007.01.014

Biswas, A., Biswas, B. K., Ito, J., Takaoka, O., Yagi, N., Itoh, S., \& Takii, K. (2011). Soybean meal can partially replace enzyme-treated fish meal in the diet of juvenile Pacific bluefin tuna Thunnus orientalis. Fisheries Sciences, 77, 615-621. http://dx.doi.org/10.1007/s12562-011-0363-6

Bonaldo, A., Roem, A. J., Pecchini, A., Grilli, E., \& Gatta, P. P. (2006). Influence of dietary soybean meal levels on growth, feed utilization and gut histology of Egyptian sole (Solea aegyptiaca) juveniles. Aquaculture, 261, 580-586. http://dx.doi.org/10.1016/j.aquaculture.2006.08.013

Bureau, D. P., Harris, A. M., \& Cho, C. Y. (1998). The effects of purified alcohol extracts from soy products on feed intake and growth of chinook salmon (Oncorhynchus tshawytscha) and rainbow trout (Oncorhynchus mykiss). Aquaculture, 161, 27-43. http://dx.doi.org/10.1016/S0044-8486(97)00254-8

Castro, C. A. C., Hernández, L. H. H., Araiza, M. A. F., Pérez, T. R., \& López, O. A. (2011). Effects of diets with soybean meal on the growth, digestibility, phosphorus and nitrogen excretion of juvenile rainbow trout Oncorhynchus mykiss. Hidrobiológica, 21(2), 118-125.

Cheah, S. H., Senoo, S., Lam, S. Y., \& Ang, K. J. (1994). Aquaculture of a high-value freshwater fish in Malaysia: the marble or sand goby (Oxyeleotris marmoratus, Bleeker). Naga Iclarm Quarterly, 17(2), 22-25.

Cheng, Z. Y., Ai, Q. H., Mai, K. S., Xu, W., Ma, H. M., Li, Y., \& Zhang, J. M. (2010). Effects of dietary canola meal on growth performance, digestion and metabolism of Japanese seabass, Lateolabrax japonicus. Aquaculture, 305, 102-108. http://dx.doi.org/10.1016/j.aquaculture.2010.03.031

Culling, C. F. A. (1974). Handbook of histopathological and histochemical techniques (3rd ed., p. 712). Butterworth, London.

Dei, H. K. (2011). Soybean as a feed ingredient for livestock and poultry, recent trends for enhancing the diversity and quality of soybean products (D. Krezhova Ed., pp. 215-226).

Elangovan, A., \& Shim, K. F. (2000). The influence of replacing fish meal partially in the diet with soybean meal on growth and body composition of juvenile tin foil barb (Barbodes altus). Aquaculture, 189, 133-134. http://dx.doi.org/10.1016/S0044-8486(00)00365-3

Fagbenro, O. A., (1999). Comparative evaluation of heat processed winged bean (Psophocarpus tetragonolobus) meals as partial replacement for fishmeal in diets for African catfish (Clarias gariepinus). Aquaculture, 170(3-4), 297-305. http://dx.doi.org/10.1016/S0044-8486(98)00409-8

Forster, I. (2002). Use of Soybean Meal in the Diets of Non-Salmonid Marine Fish. United Soybean Board. American Soybean Association. Retrieved from http://www. soyaqua. org

Francis, G., Makkar, H. P. S., \& Becker, K. (2001). Anti-nutritional factors present in plant-derived alternate fish feed ingredients and their effects in fish. Aquaculture, 199, 197-227. http://dx.doi.org/10.1016/S0044-8486(01)00526-9

Gatlin III, D. M. (2002). Use of soybean meal in the diets of omnivorous freshwater fish. Department of Wildlife and Fisheries Sciences, Faculty of Nutrition, Texas A\&M University System.

Hansen, A. C., Rosenlund, G., Karlsen, Ø. Koppe, W., \& Hemre, G. I. (2007). Total replacement of fishmeal with plant proteins in diets for Atlantic cod (Gadus morhua L.) I- effects on growth and protein retention. Aquaculture, 272, 599-611. http://dx.doi.org/10.1016/j.aquaculture.2007.08.034

Hardy, R. W. (2010). Utilization of plant proteins in fish diets: effects of global demand and supplies of fishmeal. Aquaculture Research, 41(5), 770-776. http://dx.doi.org/10.1111/j.1365-2109.2009.02349.x

Henken, A. M., Lucas, H., Tijssen, P. A. T., \& Machiels, M. A. M. (1986). A comparison between methods used to determine the energy content of feed, fish and faeces samples. Aquaculture, 58(3-4), 195-201. http://dx.doi.org/10.1016/0044-8486(86)90085-2 
Hung, S. S. O., Liu, W., Li, H. B., Storebakken, T., \& Cui, Y. B. (1997). Effect of starvation on some morphological and biochemical parameters in white sturgeon, Acipenser transmontanus. Aquaculture, 151, 357-363. http://dx.doi.org/10.1016/S0044-8486(96)01506-2

Kaushik, S. J., Covès, D., Dutto, G., \& Blanc, D. (2004). Almost total replacement of fish meal by plant protein sources in the diet of a marine teleost, the European seabass, Dicentrarchus labrax. Aquaculture, 230, 391-404. http://dx.doi.org/10.1016/S0044-8486(03)00422-8

Kechik, I. A. (1995). Aquaculture in Malaysia. In T. U. Bagarinao, \& E. E. C. Flores (Eds.), Towards Sustainable Aquaculture in Southeast Asia and Japan (pp. 125-135). SEAFDEC Aquaculture Department, Iloilo, Philippines.

Kikuchi, K., \& Furuta, T. (2009). Inclusion of blue mussel extract in diets based on fish and soybean meals for tiger puffer Takifugu rubripes. Fisheries Science, 75, 183-189. http://dx.doi.org/10.1007/s12562-008-0012-x

Knudsen, D., Jutfelt, F., Sundh, H., Sundell, K., Koppe, W., \& Frøkiaer, H. (2007). Dietary soya saponins increase gut permeability and play a key role in the onset of soybean-induced enteritis in Atlantic salmon (Salmo salar L.). British Journal of Nutrition, 1-10. http://dx.doi.org/10.1017/S0007114507886338

Kottelat, M. (2001). Fishes of Laos (p. 198). WHT Publications Ltd., Colombo 5, Sri Lanka.

Krogdahl, A., Bakke-McKellep, A. M., Røed, K. H., \& Baeverfjord, G. (2000). Feeding Atlantic salmon Salmo salar L. soybean products: effects on disease resistance (furunculosis), and lysozyme and IgM levels in the intestinal mucosa. Aquaculture Nutrition, 6, 77-84. http://dx.doi.org/10.1046/j.1365-2095.2000.00129.x

Laining, A., Ishikawa, M., Koshio, S., Lideman, \& Yokohama, S. (2011). Dietary inorganic phosphorus or microbial phytase supplementation improves growth, nutrient utilization and phosphorus mineralization of juvenile red sea bream, Pagrus major, fed soybean-based diets. Aquaculture Nutrition, 1-10. http://dx.doi.org/10.1111/j.1365-2095.2011.00914.x

Larson, H. K., \& Murdy, E. O. (2001). Eleotridae. Sleepers (gudgeons). In K. E. Carpenter, \& V. Niem (Eds.), FAO Species Identification Guide for Fishery Purposes (pp. 3574-3577). The Living Marine Resources of the Western Central Pacific. Vol. 6. FAO, Rome.

Lim, S. J., Kim, S. S., Ko, G. Y., Song, J. W., Oh, D. H., Kim, J. D., ... Lee, K. J. (2011). Fish meal replacement by soybean meal in diets for tiger puffer, Takifugu rubripes. Aquaculture, 313, 165-170. http://dx.doi.org/10.1016/j.aquaculture.2011.01.007

Lim. C., \& Akiyama, D. M. (1992). Full-fat soybean meal utilization by fish. Asian Fisheries Science, 5, 181-197.

Liu, L. W., Su, J. M., \& Luo, Y. L. (2011). Effect of partial replacement of dietary monocalcium phosphate with neutral phytase on growth performance and phosphorus digestibility in gibel carp, Carassius auratus gibelio (Bloch). Aquaculture Research, 1-10. http://dx.doi.org/10.1111/j.1365-2109.2011.02944.x

Luo, Z., Liu, Y. J., Mai, K. S., Tian, L. X., Tan, X. Y., Yang, H. J., ... Liu, D. H. (2006). Quantitative L-lysine requirement of juvenile grouper Epinephelus coioides. Aquaculture Nutrition, 12, 165-172. http://dx.doi.org/10.1111/j.1365-2095.2006.00392.x

Mai, K. S., Wan, J. L., Ai, Q. H., Xu, W., Liufi, Z. G., Zhang, L., ... Li, H. T. (2006). Dietary methionine requirement of large yellow croaker, Pseudosciaena crocea R. Aquaculture, 253, 564-572. http://dx.doi.org/10.1016/j.aquaculture.2005.08.010

Masagca, J. T., \& Sumantadinata, K. (1994). Chromosomal characters of the Indonesian sand goby, Oxyeleotris marmorata Blkr. 1874 (Eleotridae). Biotropia, 7, 41-46.

Mehner, T., \& Wieser, W. (1994). Energetics and metabolic correlates of starvation in juvenile perch (Perca fluviatilis). Journal of Fish Biology, 45, 325-33. http://dx.doi.org/10.1111/j.1095-8649.1994.tb01311.x

Pantha, M. B. (1982). The use of soybean in practical feeds for tilapia (Oreochromis niloticus). MSC. Thesis, University of Stirling, UK.

Peres, H., Lim, C. E., \& Klesius, P. H. (2003). Nutritional Value of Heat-treated Soybean Meal for Channel Catfish (Ictalurus punctatus). Aquaculture, 225, 67-82. http://dx.doi.org/10.1016/S0044-8486(03)00289-8

Refstie, S., Korsøen, Ø. J., Storebakken, T., Baeverfjord, G., Lein, I., \& Roem, A. J. (2000). Differing nutritional responses to dietary soybean meal in rainbow trout (Oncorhynchus mykiss) and Atlantic salmon (Salmo salar). Aquaculture, 190, 49-63. http://dx.doi.org/10.1016/S0044-8486(00)00382-3 
Salam, A., Ali, M., \& Masud, S. (2000). Effect of various food deprivation regimes on body composition dynamics of thaila, Catla catla. Journal of Research Science, 11(1), 26-32.

Senoo, S., Kaneko, M., Cheah, S. H., \& Ang, K. J. (1994). Egg development, hatching, larval development of marble goby, Oxyeleotris marmoratus under artificial rearing condition. Fisheries Science, 60(1), 1-8.

Shapawi, R., Ebi, I., \& Yong, A. (2013a). Soybean meal as a source of protein in formulated diets for tiger grouper, Epinephelus fuscoguttatus juvenile. Part I: Effects on growth, survival, feed utilization and body compositions. Agricultural Sciences, 4(7), 317-323. http://dx.doi.org/10.4236/as.2013.47045

Shapawi, R., Ebi, I., Yong, A., Chong, M., Lu, K. C., \& Sade, A. (2013b). Soybean meal as a source of protein in formulated diets for tiger grouper, Epinephelus fuscoguttatus juvenile. Part II: Improving diet performances $\begin{array}{llll}\text { with phytase supplementation. } & \text { Agricultural }\end{array}$ http://dx.doi.org/10.4236/as.2013.46A003

Shapawi, R., Ng, W. K., \& Mustafa, S. (2007). Replacement of fish meal with poultry by-product meal in diets formulated for the humpback grouper, Cromileptes altivelis. Aquaculture, 273, 118-126. http://dx.doi.org/10.1016/j.aquaculture.2007.09.014

Sreevatana, W. (1993). Fish diseases in Thailand: Status and problems. Proceedings of the Aquaculture Workshop for SEAFDEC/AQD Training Alumni; 8-11 September 1992; Iloilo, Philippines. SEAFDEC Aquaculture Department, Iloilo, Philippines. http://hdl.handle.net/10862/638

Stirling, H. P. (1976). Effects of experimental feeding and starvation on the proximate composition of the European bass, Dicentrachus labrax. Marine Biology, 34, 85-91. http://dx.doi.org/10.1007/BF00390791

Sverdrup-Jensen, S. (2002). Fisheries in the Lower Mekong Basin: Status and Perspectives. MRC Technical Paper No. 6. pp.103. Mekong River Commission, Phnom Penh.

Tahoun, A. M., Abo-state, H. A., \& Hammouda, Y. A. (2009). Effect of adding commercial phytase to DDGS based on the performance and feed utilization of Nile tilapia (Oreochomis niloticus) fingerlings. AmericanEurasian Journal of Agriculture and Environmental Science, 5(4), 550-555.

Tan, O. K., \& Lam, T. J. (1973). Induced breeding and early development of the marble goby (Oxyeleotris marmoratus, Blk.). Aquaculture, 2, 411-423.

Tantikitti, C., Sangpong, W., \& Chiavareesajja, S. (2005). Effects of defatted soybean protein levels on growth performance and nitrogen and phosphorus excrestion in Asian seabass (Lates calcarifer). Aquaculture, 248, 41-50. http://dx.doi.org/10.1016/j.aquaculture.2005.04.027

Tavarutmaneegul, P., \& Lin, C. K. (1988). Breeding and rearing of sand goby (Oxyeleotris marmoratus Blk.) fry. Aquaculture, 69, 299-305. http://dx.doi.org/10.1016/0044-8486(88)90337-7

Urán, P. A. (2008). Etiology of soybean-induced enteritis in fish. Ph.D. thesis dissertation. Wageningen University, The Netherlands.

Urán, P. A., Schrama, J. W., Rombout, J. H. W. M., Obach, A., Jensen, L., Koppe, W., \& Verreth, J. A. J. (2008). Soybean meal-induced enteritis in Atlantic salmon (Salmo salar L.) at different temperatures. Aquaculture Nutrition, 14, 324-330. http://dx.doi.org/10.1111/j.1365-2095.2007.00534.x.

Venou, B., Alexis, M. N., Fountoulaki, E., \& Haralabous, J. (2006). Effects of extrusion and inclusion level of soybean meal on diet digestibility, performance and nutrient utilization of gilthead sea bream (Sparus aurata). Aquaculture, 261, 343-356. http://dx.doi.org/10.1016/j.aquaculture.2006.07.030

Webster, C. D., Yancey, D. H., \& Tidwell, J. H. (1992). Effect of partially or totally replacing fish meal with soybean meal on growth of blue catfish (Ictalurus furcatus) Aquaculture, 103, 141-152. http://dx.doi.org/10.1016/0044-8486(92)90408-D

Weeks, C., Garling, D., Barrows, F. T., \& Faisal, M. (2010). The effect of feeding varying levels of soybean meal in high-nutrient-density diets on growth performance and body composition of juvenile Atlantic salmon. North American Journal of Aquaculture, 72, 279-289. http://dx.doi.org/10.1577/A09-040.1

Yang, Y. H., Wang, Y. Y., Lu, Y., \& Li, Q. Z. (2010). Effects of replacing fish meal with soybean meal on growth, feed utilization and nitrogen and phosphorus excretion on rainbow trout (Oncorhynchus mykiss). Aquaculture International, 19, 405-419. http://dx.doi.org/10.1007/s10499-010-9359-y 
Yigit, M., Ergün, S., Türker, A., Harmantepe, B., \& Erteken, A. (2010). Evaluation of soybean meal as a protein source and its effect on growth and nitrogen utilization of black sea turbot (Psetta maeotica) Juveniles. Journal of Marine Science and Technology, 18(5), 682-688.

Yu, D. H., Gong, S. Y., Yuan, Y. C., \& Lin, Y. C. (2012). Effects of replacing fishmeal with soybean meal on growth, body composition and digestive enzyme activities of juvenile Chinese sucker, Myxocyprinus asiaticus. Aquaculture Nutrition, 19(1), 84-90. http://dx.doi.org/10.1111/j.1365-2095.2012.00945.x

Zhou, Q. C., Wu, Z. H., Chi, S. Y., \& Yang, Q. H. (2007). Dietary lysine requirement of juvenile cobia (Rachycentron canadum). Aquaculture, 273, 634-640. http://dx.doi.org/10.1016/j.aquaculture.2007.08.056

\section{Copyrights}

Copyright for this article is retained by the author(s), with first publication rights granted to the journal.

This is an open-access article distributed under the terms and conditions of the Creative Commons Attribution license (http://creativecommons.org/licenses/by/3.0/). 